Article

\title{
The Role of Seaports in Green Supply Chain Management: Initiatives, Attitudes, and Perspectives in Rotterdam, Antwerp, North Sea Port, and Zeebrugge
}

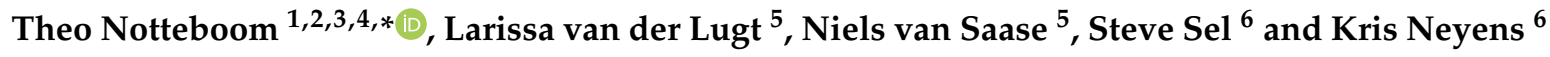 \\ 1 Center for Eurasian Maritime and Inland Logistics (CEMIL), Shanghai Maritime University, \\ Shanghai 201306, China \\ 2 Maritime Institute, Faculty of Law and Criminology, Ghent University, B-9000 Ghent, Belgium \\ 3 Faculty of Business and Economics, University of Antwerp, 2000 Antwerp, Belgium \\ 4 Antwerp Maritime Academy, 2000 Antwerp, Belgium \\ 5 Erasmus Centre for Urban, Port and Transport Economics (Erasmus UPT), 3062 PA Rotterdam, \\ The Netherlands; vanderlugt@ese.eur.nl (L.v.d.L.); vansaase@ese.eur.nl (N.v.S.) \\ 6 VIL-Flanders Innovation Cluster for Logistics, 2000 Antwerp, Belgium; steve.sel@vil.be (S.S.); \\ Kris.Neyens@vil.be (K.N.) \\ * Correspondence: theo.notteboom@gmail.com
}

Received: 31 January 2020; Accepted: 21 February 2020; Published: 24 February 2020

check for updates

\begin{abstract}
Green supply chain management (GSCM) can be defined as the integration of environmental concerns into the inter-organizational practices of supply chain management (SCM). This paper analyzes the role of seaports in the greening of supply chains in two ways. First, the fields of action to pursue GSCM objectives in ports are identified and grouped. The proposed typology includes five groups of actions, i.e., green shipping; green port development and operations; green inland logistics; seaports and the circular economy; and, actions in the field of knowledge development and information sharing. In the empirical part of the paper, this typology is used to analyze green actions and initiatives developed by market players and port authorities in the Rhine-Scheldt Delta, the leading European port region in cargo throughput terms. This structured overview of green actions and initiatives shows that these ports are hotbeds for GSCM initiatives, but progress in some areas remains slows. The second part of the analysis focuses on the attitudes and perceptions of port-related actors towards the greening of port-related supply chains. A large-scale survey conducted in the Belgian and Dutch logistics and port industry reveals that greening has been put massively on the agenda by the firms between 2010 and now. The results give a clear view on the diverse drivers and impediments towards the greening of supply chains. In addition, one can still see a gap between words and actions. The survey further points to the role of governments as catalysts or soft enforcers for change, and calls for continuity and coherence in government policy. This paper is the first study providing a comprehensive analysis on initiatives, approaches, and perspectives of port-related actors in a specific multi-port region.
\end{abstract}

Keywords: seaport; green supply chain management; drivers; impediments; initiatives; Rotterdam; Antwerp; Rhine-Scheldt Delta

\section{Introduction}

In past decades, green supply chain management (GSCM) has developed in view of integrating environmental concerns into the inter-organizational practices of supply chain management. Tighter 
regulatory requirements, and strong demands for a cleaner and more sustainable environment exerted by communities at large, are pushing GSCM practices to the next level. The sense of urgency rises with an escalating deterioration of the environment, e.g., diminishing raw material resources, proven climate change impacts, and increasing levels of pollution. As nodes in global supply chains, ports generate environmental impacts through their various functions linked to cargo handling, connectivity to maritime and land transport networks, industrial and semi-industrial activities, logistics and distribution activities, and energy production and distribution. The emergence of the 'green port' concept is closely associated with the growing environmental awareness of seaport actors.

This paper analyzes the role of seaports in the greening of supply chains. It is the first study providing a comprehensive analysis on the role of ports in GSCM covering initiatives, approaches, and perspectives of port-related actors in a specific multi-port region. The conceptual insights are applied to the ports in the Rhine-Scheldt Delta area, Europe's most important port area in cargo throughput terms. The role of seaports in GSCM is analyzed in two ways. First, several fields of action to pursue GSCM objectives are identified and grouped for private and public actors involved in port-related activities. We present a novel typology which makes a distinction between actions in the areas of green shipping; green port development and operations; green inland logistics; seaports and the circular economy; and, actions in the field of knowledge development and information sharing. This typology is used to analyze green actions and initiatives developed by market players and port authorities in the Rhine-Scheldt Delta ports. The second part of the analysis focuses on the attitudes and perceptions of port-related actors by using a large-scale survey conducted in the Belgian and Dutch logistics and port industry. The survey outcomes are analyzed in detail with attention for possible linkages between the answers and differences in the answer patterns among respondent groups. This paper concludes with a summary of the findings and a set of recommendations for the business communities in the Rhine-Scheldt Delta region, and beyond, in view of advancing the implementation of GSCM practices in seaports.

\section{Green Supply Chain Management and the Role of Seaports}

Supply chain management (SCM) is the coordination and management of a complex network of activities involved in delivering a finished product to the end-user or customer. While Ahi and Searcy [1] found a total of 22 definitions, green supply chain management (GSCM) can be defined as integrating environmental concerns into the inter-organizational practices of SCM [2,3]. In the 1990s, environmental management started to become more integrated in overall operations and a means to gain competitive advantage and economic benefits (see e.g., [4]). The idea of using environmental strategies to gain competitive advantage was further developed by Porter and van der Linde [5]. The greening of supply chains does not have to be a burden, but could constitute a potential source of competitive advantage [6]. These ideas further ripened in the early 2000s with a growing awareness that GSCM could constitute a business value driver, not just a cost center [7].

The main idea of GSCM is to strive for a reduction in environmental impacts by focusing on a series of R's throughout the supply chain: Reduce, Re-use, Recycle, Remanufacture, Reverse logistics, etc. [8]. The fields of actions in GSCM include:

- eco-design and green process engineering;

- green procurement and purchasing (see [9]);

- green production/remanufacturing and industrial ecology [10] with minimum energy and resource consumption, a green energy mix, and the application of techniques for product recovery and waste management;

- circular economy and reverse logistics, and models to share or use products instead of owning them outright;

- environmental management systems (EMS) or "a collection of internal policies, assessments, plans, and implementation actions affecting the entire organization and its relationships with the 
natural environment" [11]. Darnall et al. [12] demonstrate that organizations that adopt an EMS more frequently implement GSCM practices, regardless of how long the EMS has been in place. This suggests that EMS and GSCM may complement each other;

- green logistics, distribution and transportation: From a logistics point of view, advancing GSCM requires a massive re-engineering of supply chains in favor of eco-friendly packaging, eco-friendly transport mode choice, load and route optimization, green distribution networks and distribution hubs, and a modal shift to environmental-friendly transport mode combinations and synchromodality. Modal shift and 'co-modality' policies have been implemented by supranational, national, and regional governments aimed at stimulating the use of barges, rail, and shortsea shipping. In the meantime, the terms modal shift and co-modality have made room for the notion of 'synchromodality'. The Platform Synchromodality defines this notion as "the optimally flexible and sustainable deployment of different modes of transport in a network under the direction of a logistics service provider, so that the customer (shipper or forwarder) is offered an integrated solution for his (inland) transport". A key characteristic of the concept is that not one single kind of party is leading in finding and implementing a synchromodal solution. Shipping lines, terminal operators, inland terminals, inland transport operators, 3PL companies, shippers, and public authorities all have their role to play in the development of synchromodal solutions. Co-ordination and co-operation between supply chain partners [13] and the use of digital and integrated data solutions are key to support the above fields of actions.

A seaport is a logistic and industrial node accommodating seagoing vessels and characterized by a functional and spatial clustering of cargo transport, storage, and transformation processes linked to global supply chains [14]. Ports, as nodes in extensive global transport networks, and intersections of large bundles of supply chains, create environmental impacts and adverse effects on earth's climate through their logistics function (i.e., transport, terminal, and warehousing activities) and industrial and semi-industrial function (i.e., goods and energy production, assembly, and recycling activities). Moreover, maritime operations of ships visiting the port and landside connectivity cause environmental impacts. Therefore, ports as nodes in global supply chains have a role to play in GSCM. The emergence of the 'green port' concept is closely associated with the growing environmental awareness of seaport actors. Pavlic et al. [15] define green port as 'a product of the long-term strategy for the sustainable and climate friendly development of port's infrastructure'. The green port concept means responsible behavior of all stakeholders involved in port management and operations. Doerr [16] provided an overview of policies and strategies for sustainable ports across the world. Lam and Notteboom [17] conduct an exploratory and comparative review of the range of 'greening' tools available to port authorities in leading ports of Asia and Europe. Acciaro et al. [18] defined a set of quantitative objectives to evaluate the success of innovations with respect to environmental sustainability in seaports. In business practice, the growing green reflex is mirrored in the many green initiatives of individual ports, and the coordinated actions of the wider port community, as exemplified in Europe by the EcoPorts foundation (embedded in the European Sea Ports Organisation - ESPO). Puig et al. [19] provided a good overview of current environmental issues in seaports and the overall performance of European ports in terms of environmental management.

Finally, it needs to be noted that GSCM in seaports and the 'green port' concept mainly focus on environmental and climate change aspects of the sustainability concept. The 2030 Agenda for Sustainable Development of the United Nations, as captured by the UN Sustainable Development Goals, includes 17 goals and, thus, covers a much wider spectrum of sustainability objectives. GSCM in ports primarily helps in the pursuit of Goal 7 ('Ensure access to affordable, reliable, sustainable and modern energy for all'), Goal 12 ('Ensure sustainable consumption and production patterns'), Goal 13 ('Take urgent action to combat climate change and its impacts'), Goal 14 ('Conserve and sustainably use the oceans, seas and marine resources for sustainable development'), and Goal 17 ('Strengthen the means of implementation and revitalize the global partnership for sustainable development'). Nevertheless, ports are focusing on all 17 goals and thus go beyond GSCM practices 
only. For example, International Association of Ports and Harbors (IAPH) launched the World Ports Sustainability Program (WPSP) in 2017 together with The American Association of Port Authorities (AAPA), the European Sea Ports Organisation (ESPO), the International Association of Cities and Ports (AIVP), and the World Association for Waterborne Transport Infrastructure (PIANC). Using the 17 UN Sustainable Development Goals as the foundation, the program wants to enhance and coordinate future sustainability efforts of ports worldwide and foster international cooperation with partners in the supply chain. Next to organizing events, the WPSP program is developing a global database of port related projects on sustainable development to raise awareness, share experiences and provide inspiration.

\section{Methodology}

The role of seaports in the greening of supply chains forms the core of the presented research. To investigate this role, our methodological approach is based on two pillars: (1) the introduction of a typology on GSCM initiatives that can be developed by port-related actors and (2) an assessment of attitudes and perspectives of these actors on GSCM.

To advance the first methodological pillar, we present a novel topology on fields of actions in GSCM relevant to ports and their actors. Based on extant literature, we present five fields of action for private and public actors involved in port-related activities to pursue GSCM objectives (Figure 1). Section 4 presents a concise and structured discussion of concrete actions in each of these domains of the presented typology, supported by relevant literature for further reading and insights.

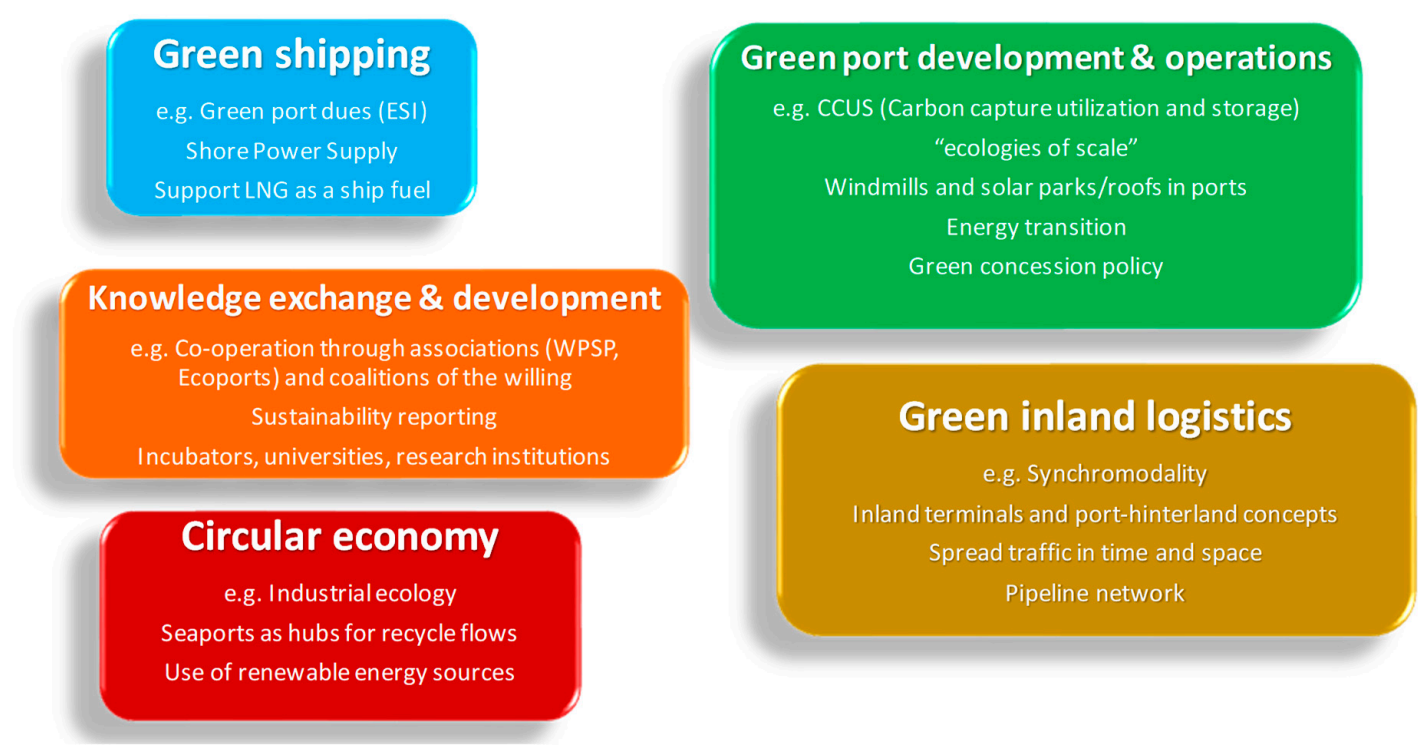

Figure 1. Fields of action for private and public actors involved in port-related activities to pursue green supply chain management (GSCM) objectives.

Next, the above typology is empirically applied to analyze green actions and initiatives developed by market players and port authorities in the Rhine-Scheldt Delta ports. This port system in the Netherlands and Belgium handled about 925 million tons in 2018 or about a quarter of the total port throughput in the EU28 (Figure 2). Next to being large cargo handling platforms, the ports in the Rhine-Scheldt Delta are home to a large diversity of industrial activities, such as steel plants (ArcelorMittal and Tata Steel), automotive plants (Volvo Cars and Trucks), energy plants, and energy-related industries. However, the largest industrial activity in the Delta is related to petrochemical and chemical companies. The presented application to one of the most prominent port systems in the world not only makes the typology more concrete, but also provides a basis for evaluating to what extent initiatives are effectively planned or have been implemented in each of the five fields of action. 


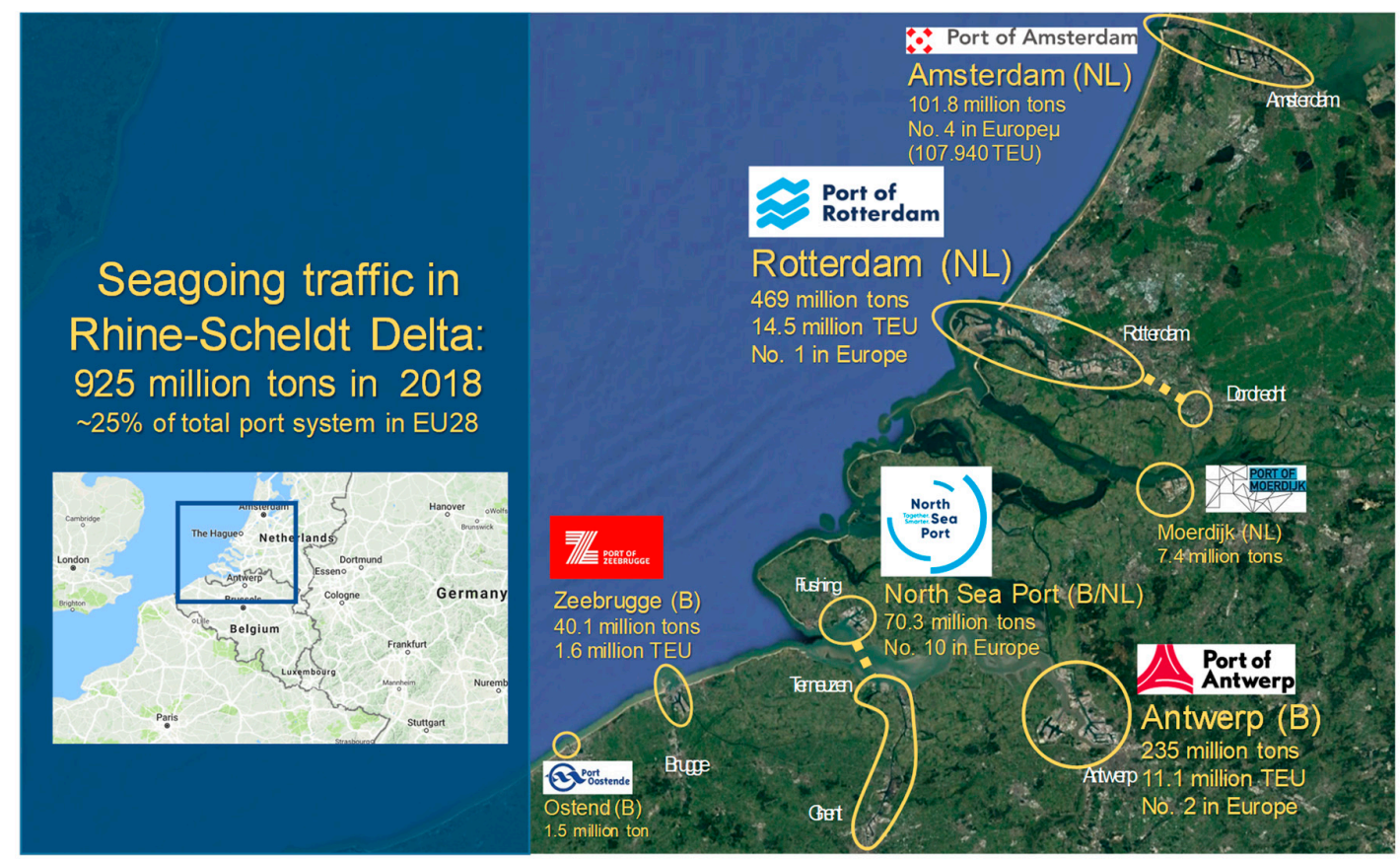

Figure 2. Port locations and maritime traffic (seagoing) in the Rhine-Scheldt Delta.

The second part of the analysis focuses on the attitudes and perceptions of port-related actors. To be consisting with the empirical setting of planned and implemented initiatives, we conducted a large-scale survey in the Belgian and Dutch logistics and port industry. The survey was conducted in the period February-May 2019. The questionnaire contained 22 questions that surveyed the relevance, the rate of implementation, the acceptance and support, specific activities, incorporation of the GSCM theme into company management, drivers and obstacles, balance of power, the role of government and administration, key performance indicators, commercial aspects, and the current and future perceived role for each stakeholder in leading the way to green supply chains. Survey software was used to process the answers and to detect differences between respondent groups.

The target group of the survey consisted of a wide range of companies including terminal operators, shipping companies, shipping agencies, logistics service providers, port industry companies, shippers, manufacturing companies, wholesalers and importers, freight forwarders, transport companies, etc. A total of 650 companies were invited to participate in the survey. The list was compiled based on a selection of the members of VIL (Flanders Innovation Cluster for Logistics), input obtained from the port authorities, and the customer database of a major bank active in ports and logistics. Port association Deltalinqs assisted in distributing the survey in the Rotterdam port community. The target group was divided into the following sub-categories: transport companies; freight forwarders; 3PL logistics service providers; shipping companies (including shipping companies, short sea shipping operators, inland navigation companies, shipping agencies and nautical service providers); terminal operators; retail, import/export wholesale companies; manufacturing / industrial companies; IT-providers; and the services sector (banks, insurance, etc.). The survey was made available to respondents through a web-based survey application and supported by an invitation letter.

A total of 93 fully completed surveys were received, implying a net response rate of $14.3 \%$, with mainly transport companies, manufacturing/industrial companies, terminal operators, 3PL logistics service providers, and freight forwarders as the groups best represented in the population (Figure 3). The survey was sent mainly to C-level (Chief Executive Officer, Chief Financial Officer, etc.) or senior management positions. This was reflected in the answers: $57 \%$ of respondents were of C-level (or owner), $34.4 \%$ consisted of senior management or vice-president level, and $5.4 \%$ was composed of people working at managerial level. 


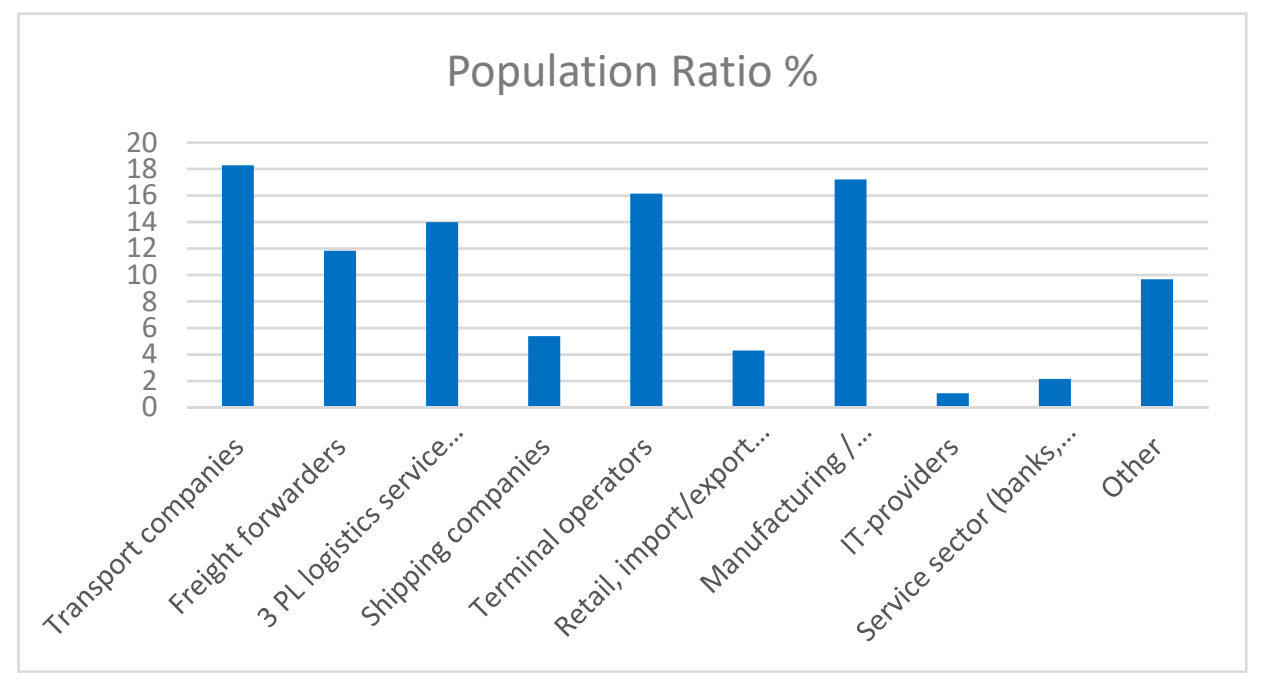

Figure 3. Survey response population ratio per category.

Most questions were mandatory and presented several statements. The results of these questions will be presented in percentages. A limited set of open questions was also put forward. In Section 5 we present a theme-based analysis of the survey results with attention for possible linkages between the answers, and differences in the answer patterns among respondent groups.

\section{Typology of Fields of Action in GSCM}

\subsection{Green Shipping}

Ships do not only emit harmful substances when sailing. Ships are also major contributors to emissions in ports, even when they are idle or berthed. A study of Organization for Economic Cooperation and Development (OECD) argues that shipping emissions in ports account for 18 million tons of $\mathrm{CO} 2$ emissions, 0.4 million tons of NOx, 0.2 million of Sox, and 0.03 million tons of PM10 in 2011. Around $85 \%$ of emissions come from containerships and tankers [20]. Next to supranational regulation from International Maritime Organization (IMO), seaports and their actors have a role to play to reduce ship emissions in ports. The main fields of action are related to the following:

- Reduce ship emissions in ports by decreasing waiting times and the turnaround time of vessels in port: this can be done by, for instance, synchronizing and integrating the nautical chain (which includes pilotage, towage, lock operations, etc.) through optimized vessel traffic management systems. In addition, terminal operators can play a major role to limit the vessel turnaround time at the terminal;

- Implement green port dues and voluntary green shipping schemes: ports can implement voluntary programs to incentivize ship operators to green their ships. Green ship operators in return receive a benefit, such as a discount in port dues (see e.g., the Environmental Ship Index (ESI) initiated by the International Association of Ports and Harbours (IAPH));

- Implement cold ironing, shore power supply, or alternate marine power (AMP): Seagoing vessels and barges at berth use shore power for the auxiliary engines instead of bunker fuel. At present, cold ironing is most widespread in the cruise shipping market and ferry business. There are challenges related to the investment cost (terminal and ship), the division of these costs between different stakeholders (shipping line, terminal operator, and port authority), and the break-even cost compared to bunker fuel. Shipping lines are not always eager to invest in the retrofitting of ships as long as cold ironing possibilities are limited to only a few ports of call ('chicken and egg' problem). Moreover, the large-scale application of cold ironing in a port might require extensive capacity upgrading of the local or regional power grid. Finally, the environmental advantages of cold ironing depend on how clean the shore-based electricity production process is; 
- Support the transition to liquified natural gas (LNG) as a ship fuel: The systematic literature review in [21] presented perspectives of and challenges for the adoption of LNG as a ship fuel. In the past five years, investments in LNG bunkering infrastructure in ports have really taken off. Quite a few public port authorities are playing a proactive role in facilitating the use of LNG as a marine fuel, often in close partnership with industrial actors [22].

\subsection{Green Port Development and Operations}

Green port development is about actions in ports that make the port and its environment greener and more sustainable. Within port areas, a lot of greenhouse gases (GHG) are emitted into the atmosphere, mainly due to industrial and transportation activities. Multiple instruments and concepts of green port development and operations exist including:

- Develop a green concession policy by implementing green elements in terminal concession procedures and contracts [23];

- Maximize the 'ecologies of scale' in industrial clusters. Ecologies of scale are achieved in the (petro)chemical industry when companies utilize each other's waste material or by-products, such as heat. It would be far more difficult to achieve this when the plants concerned would be spatially scattered. Environmental zoning and co-siting/location can help to achieve these effects;

- Develop green zones and buffers in the port area with nature forming a shield between heavy port industry and residential areas [24];

- Develop wind and solar parks and wave energy, combined with Port Energy Management (PEM; see [18];

- Implement Carbon Capture and Storage (CCS) and fume return systems: the process of CCS consists of three steps, which are capturing, transportation, and storage [25]. Carbon can also be used as a base for other products, i.e. Carbon Capture and Utilization (CCU);

- Support the production of bio-fuels and bio-based chemicals: A biofuel is a hydrocarbon that is made by, or coming from, a living organism that humans use to power something. Ports that have good access to biomass and a good transportation network can be smart places to locate production facilities for biofuels;

- Use low-emission or zero-emission quay and yard equipment on terminals (see e.g., [26] on the energy efficiency of terminals and [27] on the economic viability of battery-electric automated guided vehicles orAGV);

- Reduce idling of ships and inland transport modes and waiting times at terminals through information sharing on the chains via data platform, vessel dependent time windows [28], or truck appointment management solutions or pricing systems (TAS; see e.g. [29] and [30]);

- Develop green warehousing and distribution activities in ports through optimal location choice, optimal distribution system design, sustainable warehouse design (e.g., LED lighting and smart cooling/heating systems), energy, and material recycling.

\subsection{Green Inland Logistics: Modal Shift, Synchromodality, and Inland Terminals}

Inland logistics comprises the transportation of goods from the hinterland to the port or from the port to the hinterland via barge, rail, truck, or pipeline. GSCM actions can include the following:

- Make the multimodal transport system greener by stimulating a modal shift and implement synchromodal transport solutions through pricing (taxes and incentives), regulation on emission standards, information provision to users, a liberalization of freight markets, and infrastructure investments to make certain transport modes more attractive. Behdani et al. [31] and Tavasszy et al. [32] explain their vision on synchromodality as following: a horizontal integration of freight transportation planning, which allows for parallel usage of different transportation modes from origin to destination. Pfoser et al. [33] describe the most important requirements for synchromodal transportation to work: close cooperation of all stakeholders within the transport 
chain, technical ICT infrastructure to share chain information and optimize logistic flows, and a proper physical infrastructure;

- Optimize the use of each modality by reducing empty kilometers, the improvement of vehicle utilization rates, and scale increases in transport modes (vessel scale, train length and tonnage, truck platooning, etc.);

- Implement smart planning by bundling cargo within a company or between companies. The latter demands horizontal co-operation (see [34]);

- Support the transition to a greener energy mix for transport by imposing minimum emissions standards on vehicles entering the port area (e.g., Clean Truck Program, part of the San Pedro Bay Ports Clean Air Action Plan) and by giving incentives for the use of non-fossil fuels;

- Promote the role of inland terminals and port-hinterland concepts in GSCM: many market players and port authorities have come to understand that landside operations are key to a successful integration along the supply chain and to move to a greener port-hinterland connectivity. A number of shipping lines extend their scope beyond terminal operations to include inland transport and logistics [35]. Some terminal operators in Europe are also increasing their influence throughout supply chains by engaging into inland transport. They seem to do so mainly by incorporating inland terminals as 'extended gates' to seaport terminals [36];

- Develop new or renewed transport modes in a seaport context, such as underground freight transport (UFT) [37], such as the Hyperloop concept;

- Implement green inland-focused port dues: port authorities can influence the greening of hinterland transportation activities by applying port dues as a tool, see [38];

- Develop advanced and integrated traffic management systems for rail, barge and truck;

- Implement pricing mechanisms and other instruments to spread traffic in time and space: tools such as appointment systems, fixed time windows, peak pricing, or extended (night) opening hours of terminals can lead to a better utilization of terminals and less waiting hours for transport operators [39];

- Development of pipeline network (intra-port, inter-port and port-hinterland): pipeline networks can be used for transportation of liquids over both short and long distances. Pipeline transportation is cleaner than other transport modes such as truck, rail and barge, and is essential for the development of a circular economy.

\subsection{Seaports and the Circular Economy}

Preston [40] describes the circular economy as: "restructuring the industrial systems to support ecosystems through the adoption of methods to maximize the efficient use of resources by recycling and minimizing emissions and waste". Van Dooren and Braam [41] distinguish four focus areas of ports to create a circular economy: (1) minimizing the use of inputs and eliminate waste and pollution, (2) maximize the created value at each stage, (3) manage flows of bio-based resources and recovery of flows on non-renewables into a closed loop, and (4) establish mutually beneficial relationships between companies within each circular chain. In a port context, the main fields of action are:

- Promote industrial ecology: industrial ecology attempts to optimize waste management by making interactions between stakeholders within the same geographical area stronger (e.g., exchanging materials, water, and by-products). This functions best when industries with synergies are located in close proximity to each other [42];

- Develop seaports as hubs for recycle flows: ports are well-suited to serve as a hub in international recycling flows due to the already existing seaport infrastructure and international connectivity [43]. Within these hubs, recycling flows are delivered, transformed into new products, and re-exported around the world;

- Use renewable energy sources: ports are well-suited for the generation of renewable energy, for example, via hydro- and offshore power installations [44]. 


\subsection{Knowledge Development, Information Sharing, and Exchange of Best Practices}

This field of actions includes measures that facilitate knowledge development, information sharing, and exchange of best practices in the field of GSCM in seaports. A non-exhaustive list of some areas for initiatives is presented below:

- Develop interactive environmental and energy information and management systems which enrich business processes with new knowledge about energy consumption and emissions, and lead to a better understanding of activities and processes, allowing stakeholders to better plan their strategies;

- Co-operate in the framework of port-related associations: port authorities and port-related firms can exchange knowledge and best practices on green ports and green supply chains, and jointly aim for innovation in these fields through a broad range of associations, ad hoc co-operation arrangements, and partnerships of all sorts;

- Implement environmental strategies of ports combined with or integrated in broader corporate social responsibility (CSR) strategies and stakeholder relations management: Corporate social reporting (CSR) is concerned with learning about the effect an organization has on society and allows the organization to be accountable for these responsibilities. A lot of port authorities, port companies, and branch organizations have developed extensively sustainability and CSR programs to improve the social and environmental performance of the port cluster and to improve communication and exchanges on these topics with a broad range of stakeholders (environmental groups, community groups, the press, government, port users, etc.), see e.g. [45] on Australian seaports and [46] on how port innovation initiatives respond to the CSR goals;

- Implement sustainability reporting at company, port authority or port industry level: the port industry is adopting this sort of reporting to conceptualize sustainability and as an essential basis for the license to operate ([47]. Mainly larger port authorities have started producing sustainability reports [48]. In 2016, the first Sustainability Report at the level of the European Port Industry was presented;

- Develop the local knowledge base on GSCM in ports: to drive innovation in the port cluster, actors develop a broad range of local initiatives, such as the setting up of incubators and smart-labs for start-ups and scale-ups, the organization of Hackathon events to create usable software or hardware, co-operation (agreements) with universities and research institutions, and creating a good business environment for research and development (R\&D) focused firms, research centers, consultancy firms, and start-ups.

\subsection{Empirical Application: GSCM Initiatives in the Rhine-Scheldt Delta Ports}

Figures 4-8 provide an overview of the fields of action in GSCM in the Rhine-Scheldt Delta ports. The discussion follows the typology of measures, tools, and instruments presented earlier. The (leading) actor or initiator involved is also identified.

In the Rhine-Scheldt Delta, all port authorities are corporatized landlord port authorities resulting from gradual corporatization processes. In practice, this implies port authorities have a public limited company status and have financial and managerial autonomy to develop and implement port strategies. The port authorities in the Rhine-Scheldt Delta, just like many other ports around the world, are pursuing a greening of port management to safeguard their license to operate, to comply with, and anticipate to environmental regulation, and to increase their economic and environmental competitiveness. It has also become a clear mission in the context of corporate social responsibility (CSR) and stakeholder relations management in port areas $[49,50]$. Other actors include port and terminal operating companies; supply chain and transport organizers, such as forwarders, shipping agencies, and logistics service providers; companies involved in industrial and semi-industrial activities in the port area; associations, government agencies, and non-governmental organizations (NGOs). Furthermore, industry and branch organizations often play an important role in bringing companies together to 
take joint initiatives in GSCM. Port community associations (e.g., Deltalinqs in Rotterdam, Alfaport in Flemish ports, etc.), branch organizations (e.g., Fedichem, Koninklijke Belgische Redersvereniging, etc.), environmental groups (e.g., Natuurpunt), and community groups of all kinds also contribute to the stakeholder debate on the greening of ports and port-related supply chains. In other cases, private companies (sometimes with different backgrounds) and other organizations (such as public entities) form 'coalitions of the willing' to advance the design and implementation of GSCM solutions. These coalitions are associated with new models of governance to build trust among the parties involved and to achieve a fair distribution of costs/efforts and revenues/returns [51-54]. Finally, service providers (such as banks, insurance companies, classification and certification societies, rating agencies, IT companies, and start-ups, etc.), research institutes, universities, and innovation centers of all sorts contribute to the search for novel ways to support GSCM practices in the port context.

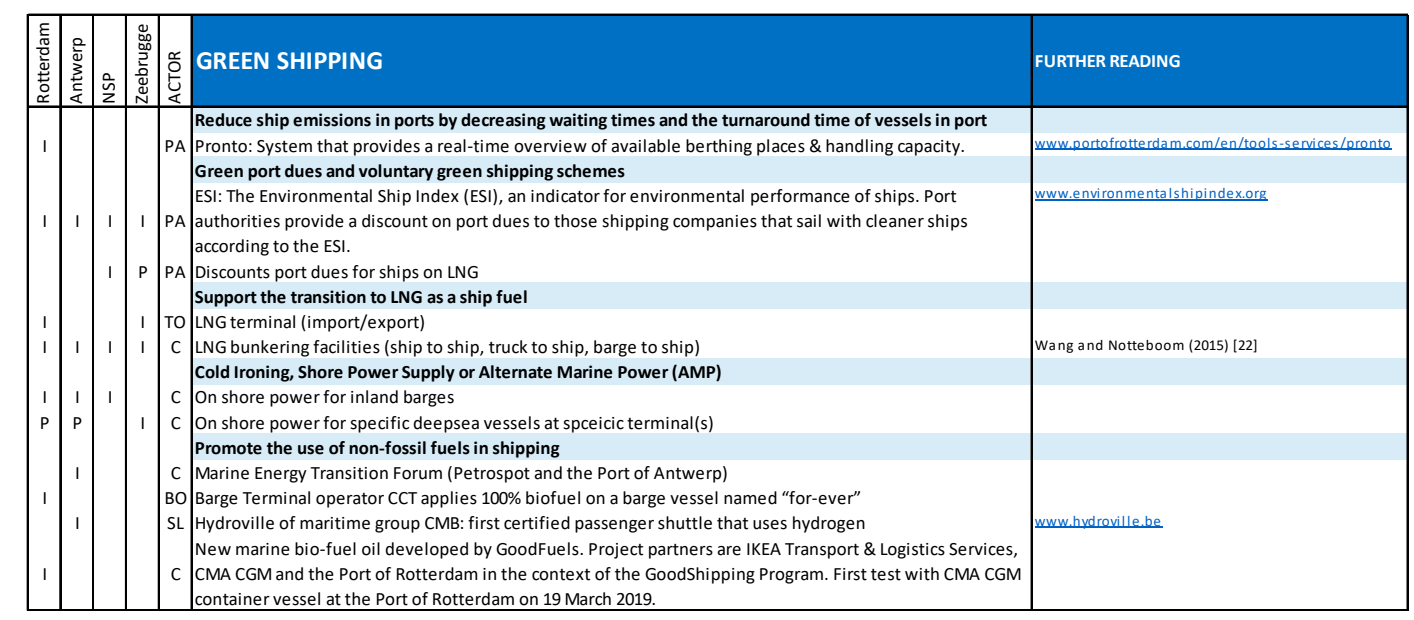

Figure 4. Green shipping. Notes. NSP = North Sea Port; Status: $\mathrm{I}=$ implemented, $\mathrm{P}=$ planned; Actor: $\mathrm{C}=$ consortium with different partners, $\mathrm{PA}=$ port authority, $\mathrm{TO}=$ terminal operator, $\mathrm{BO}=$ barge operator, $\mathrm{SL}=$ shipping line, $\mathrm{IC}=$ industrial company.

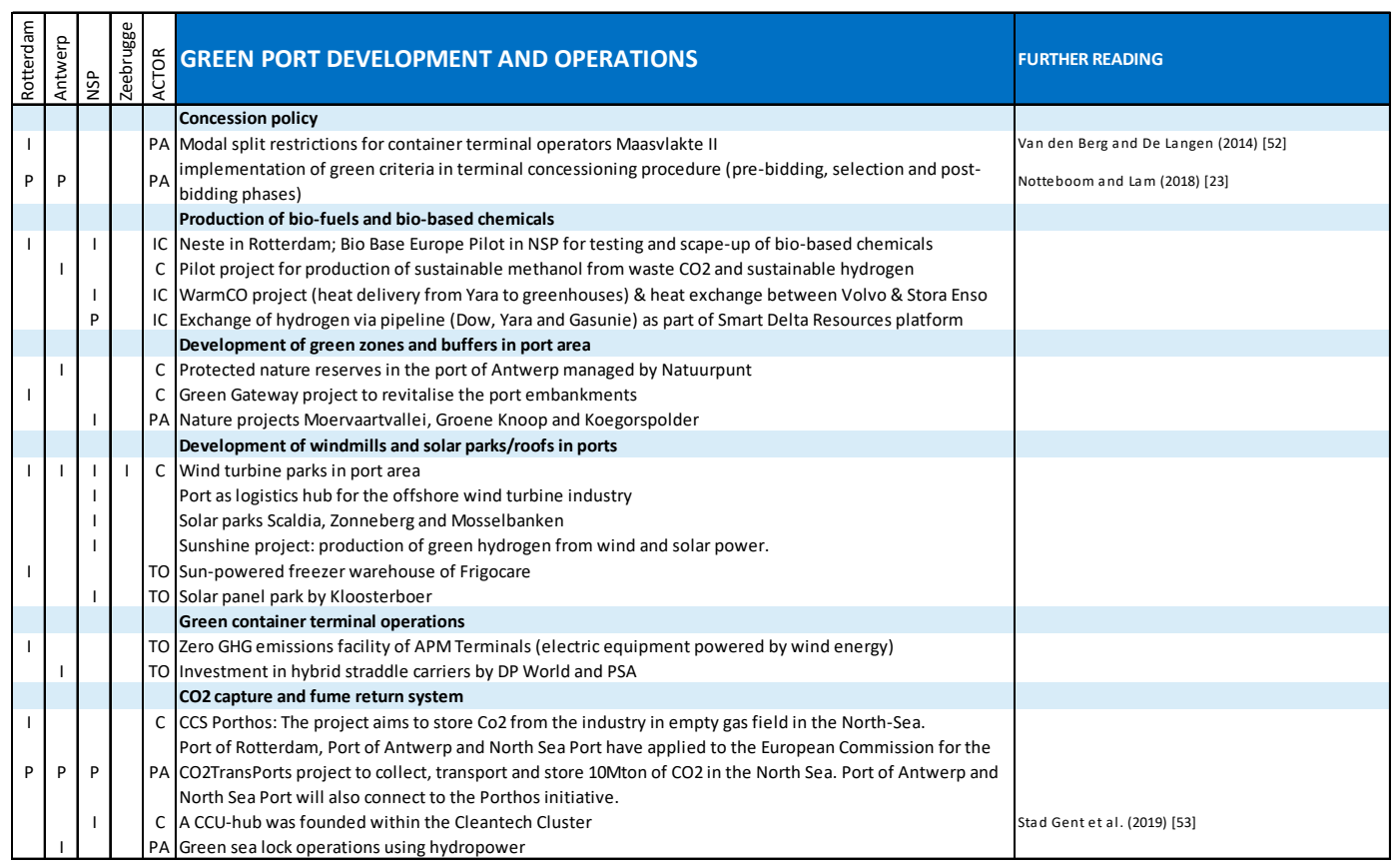

Figure 5. Green port development and operations. 


\begin{tabular}{|c|c|c|c|c|c|c|}
\hline \multicolumn{2}{|c|}{ 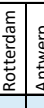 } & $\frac{\hat{n}}{z}$ & 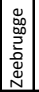 & 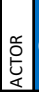 & GREEN INLAND LOGISTICS & FURTHER READING \\
\hline \multirow{5}{*}{1} & & & & & The organization of the use of the multimodal transport system / Optimization of the use of each modality / & Smart planning \\
\hline & 1 & & & $\begin{array}{ll}\text { PA } \\
P A \\
P A\end{array}$ & $\begin{array}{l}\text { Port of Antwerp Intermodal Solutions/ a collaboration within the Antwerp port community that offers } \\
\text { concrete solutions to improve connectivity with the hinterland. } \\
\text { Port of Antwerp Connectivity Platform to better inform the customers about the various transport options } \\
\text { and the most optimal way in which they can take their goods to their destination. } \\
\text { Navigate: tool that gives a complete overview of the most efficient connections via Rotterdam by deepsea, } \\
\text { shortsea, rail or barge. } \\
\text { Research on digital initiatives and planning tools around synchromodality (TNO, EUR) }\end{array}$ & $\begin{array}{l}\text { https://www.portofantwerp.com/nl/intermodal- } \\
\text { solutions-connectivity-platform } \\
\text { https://www.portofrotterdam.com/en/tools-. } \\
\text { services/navigate }\end{array}$ \\
\hline & & & & & Pricing mechanisms and other instruments to spread traffic in time and space & \\
\hline & 1 & $\mathrm{P}$ & & TO & $\begin{array}{l}\text { Extended working hours at landside termnials Deurganckdock } \\
\text { Central Gate project: a decentralized parking facility in port area linked to a uniform automatic registration } \\
\text { (biometrics). }\end{array}$ & \\
\hline & & & & & Promoting the role of inland terminals and port-hinterland concepts in GSCM & \\
\hline 1 & \multirow[t]{2}{*}{1} & & \multirow[t]{2}{*}{ I } & \multirow[t]{2}{*}{ TO } & $\begin{array}{l}\text { Extended Gate concept and European Gateway Services of ECT/HutchisonPorts } \\
\text { Port-hinterland concepts and services to connect deepsea terminals to inland platforms (DP World and PSA } \\
\text { in Antwerp; Cosco in Zeebrugge; MSC and Maersk Line; barge operators, rail operators, etc..) }\end{array}$ & Veenstra et al. (2012) [54] \\
\hline & & & & & Smart planning - Advanced and integrated traffic management systems for barge & \\
\hline & 1 & \multirow[t]{2}{*}{1} & & \begin{tabular}{|l|} 
PA \\
TO
\end{tabular} & $\begin{array}{l}\text { Minium size call project for bundling of container volumes for barges } \\
\text { ITG as transit hub between mainports and French hinterland }\end{array}$ & \\
\hline & & & & & Energy mix by use of modalities & \\
\hline 1 & \multirow[t]{2}{*}{1} & \multirow{2}{*}{\multicolumn{2}{|c|}{ I }} & $\mathrm{PA}$ & $\begin{array}{l}\text { Subsidizing projects of barge operators to reduce GHG emissions such as } \mathrm{CO} 2, \mathrm{CH} 4, \mathrm{NOx} \text { and PM (25\% for } \\
\text { research projects and } 75 \% \text { for concrete project implementations) } \\
\text { EU's CLINSH project (CLean INland SHipping) }\end{array}$ & \multirow[t]{3}{*}{ www.clinsh.eu } \\
\hline & & & & & Development of pipeline network (intra-port, inter-port and port-hinterland) & \\
\hline 1 & $\begin{array}{l}1 \\
1\end{array}$ & 1 & 1 & \begin{tabular}{l|l} 
IC \\
PA \\
IC \\
C \\
C
\end{tabular} & $\begin{array}{l}\text { Extensive product pipeline networks to connect companies in the port and to hinterland } \\
\text { 2017: Belgian national pipeline company NMP taken over by Port of Antwerp } \\
\text { Gas pipeline hub in Europe } \\
\text { Vopak \& Port of Rotterdam Authority developed the MultiCore pipeline bundle which comprises of } 4 \\
\text { pipelines and runs along the industrial areas in the port. } \\
\text { 'Clean Underground Sustainable Transport' study (CUST) to investigate the feasibility of a pipeline } \\
\text { infrastructure in the port area to transport CO2, to distribute hydrogen or residual gasses }\end{array}$ & \\
\hline
\end{tabular}

Figure 6. Green inland logistics.

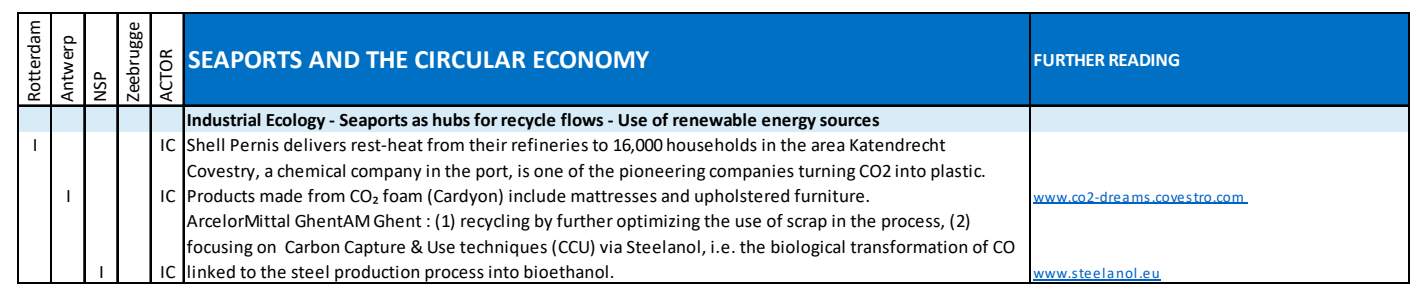

Figure 7. Seaports and the circular economy.

\begin{tabular}{|c|c|c|c|c|c|c|}
\hline 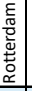 & 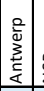 & 产 & 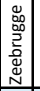 & 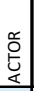 & Knowledge development, information sharing \& exchange of best practices & FURTHER READING \\
\hline & & & & & Co-operation in the framework of (port-related) associations & \\
\hline 1 & 1 & 1 & 1 & PA & Membership of and active particpation in EcoPorts of the European Sea Ports Organisation (ESPO). & www.ecoports.com \\
\hline 1 & 1 & 1 & 1 & $\mathrm{PA}$ & $\begin{array}{l}\text { World Ports Sustainability Program (WPSP) launched in Antwerp in 2017. The program wants to enhance } \\
\text { and coordinate future sustainability efforts of ports worldwide and foster international cooperation. } \\
\text { Rotterdam Climate Initiative program as part of C40 Climate Leadership Group. The objective is to halve the } \\
\text { CO2 emissions of the Rotterdam agglomeration in } 2025 \text { compared to } 1990 .\end{array}$ & https://sustainableworldports.org/ \\
\hline & & & & & Sustainability reporting at company, port authority or port industry level & \\
\hline & 1 & & & $\mathrm{PA}$ & $\begin{array}{l}\text { Sustainability reports of port authorities to communicate the progress and results of its environmental } \\
\text { monitoring and performance to stakeholders. }\end{array}$ & Geerts and Dooms (2017) [48] \\
\hline & & & & & $\begin{array}{l}\text { Environmental strategies of ports combined with or integrated in broader corporate social responsibility } \\
\text { (CSR) strategies and stakeholder relations management. }\end{array}$ & \\
\hline 1 & & & & $\mathrm{PA}$ & $\begin{array}{l}\text { Campaign 'Building a Sustainable Port' focusing on three key themes: a Safe \& Healthy Environment, } \\
\text { Climate \& Energy and People \& Employment. }\end{array}$ & \\
\hline 1 & 1 & 1 & 1 & c & $\begin{array}{l}\text { Range of environmental \& CSR initiatives in partnership with relevant stakeholders. } \\
\text { Develop the local knowledge base on GSCM in ports }\end{array}$ & \\
\hline 1 & 1 & & & \begin{tabular}{c|c}
$C$ \\
$P A$
\end{tabular} & $\begin{array}{l}\text { BlueChem: incubator for sustainable chemistry located at Blue Gate Antwerp } \\
\text { Rail Incubator in view of facilitating new rail connections. }\end{array}$ & https://bluechem.be \\
\hline 1 & I & 1 & & $c$ & $\begin{array}{l}\text { PortXL: The objective of this company is the acceleration of innovative technologies for the maritime, } \\
\text { logistics, energy and chemical industry sectors in port regions across the world. } \\
\text { Cleantech Cluster Ghent Region for the sharing of knowledge and experience in the field of energy, } \\
\text { materials, water and mobility. }\end{array}$ & https://portxl.org \\
\hline & & 1 & & c & $\begin{array}{l}\text { Smart Delta Resources is an initiative taken by eleven energy- and feedstock intensive companies } \\
\text { searching for a reduction in their use of energy and feedstock though industrial symbiosis. } \\
\text { 'Blocklab' is a field dlab for the development of concrete applications and solutions based on blockchain }\end{array}$ & https://www.smartdeltaresources.com \\
\hline 1 & & & & c & $\begin{array}{l}\text { BlockLab' is a field lab for the development of concrete applications and solutions based on blockchain } \\
\text { technology. }\end{array}$ & https://www.blocklab.nl \\
\hline & 1 & & & c & $\begin{array}{l}\text { The Beacon in Antwerp brings together major technology providers in loT, flexible start-ups and scale-ups } \\
\text { and leading researchers at a single location. The Port of Antwerp is one of the investors. }\end{array}$ & https://thebeacon.eu \\
\hline I & 1 & & & c & Hackathons: e.g. the World Port Hackathon in Rotterdam. chainPORT hackathon in Antwerp. & \\
\hline 1 & 1 & I & I & & $\begin{array}{l}\text { Specialised research institutes such as SmartPort in Rotterdam, VIL in Flanders and TKI-Dinalog in the } \\
\text { Netherlands }\end{array}$ & \\
\hline
\end{tabular}

Figure 8. Knowledge development, information sharing, and exchange of best practices. 


\section{Survey Results on GSCM Attitudes and Perspectives in the Rhine-Scheldt Delta Port Region}

\subsection{Greening as a Topic at Corporate Level}

Companies' attitudes towards GSCM can range from reactive monitoring of the general environment management programs to more proactive practices. Kopicki et al. [55] argued that companies can follow three different approaches in dealing with GSCM:

- the reactive approach: minimal resources are committed to environmental management and the focus is very much on just meeting compliance in terms of environmental regulation;

- the proactive approach: companies following this approach start to pre-empt new environmental laws by realizing a modest resource commitment to, for instance, initiate the recycling of products, reverse logistics and designing green products;

- the value-seeking approach: in this case, companies integrate environmental initiatives, and activities such as green purchasing and green transport as strategic initiatives into their business strategy.

Figure 9 presents some indicators on a company's perspective and attitude towards the greening of supply chains in the Rhine-Scheldt Delta. For almost 70\% (69.9\%) of the response group, greening has been a topic since before 2015 . The same group $(67.8 \%)$ included this in its corporate mission statement and has expanded into real actions (66.6\%) within two years after including it in their mission (2016-2017).

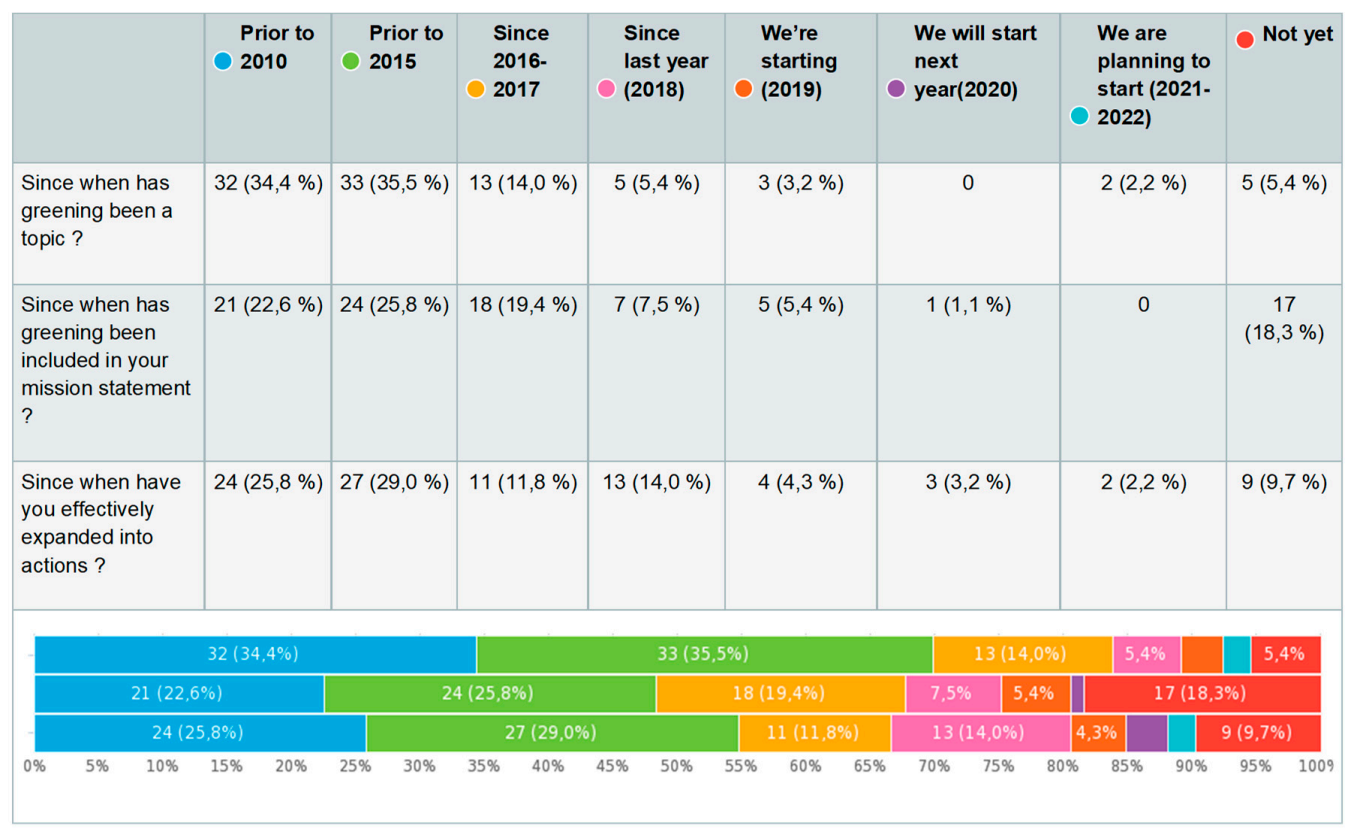

Figure 9. The relevance of and focus on greening from a corporate perspective.

When zooming in on individual respondent categories, it should be noted that the service-oriented companies (LSPs) have been significantly more aware (78\% by 2015) and active ( $80.4 \%$ by $2016-2017$ ). Only $68.3 \%$ of them had included greening in their company mission by 2016-2017. The producers, manufacturing (shippers), and retailers did not deviate from the generic response group by having it on the agenda (70\% by 2015), but a stunning $85 \%$ had included it in their company mission by 2016-2017, even though only 50\% claimed to have moved to real actions by then.

Also, important to note is that 1 out of 10 still must have a look at the topic (10.8\% as from 2019 or not yet), and that even 1 in 5 still must get into gear (19.4\% as from 2019 or not yet). Service oriented companies (LSPs) score significantly better with $7.3 \%$ (agenda) and $12.2 \%$ (action), respectively. 
The green topic often (i.e., $71 \%$ ) is an individual topic at the board or management meetings, which can be considered a good sign (Figure 10). For 7.5\% of the respondents, 'greening' is never on the agenda and for another $21.5 \%$ only once a year. Combined, this means that for $29 \%$ the topic is not a very hot one. A further detailed analysis of the results shows that greening is much more part of the corporate DNA when it concerns larger companies.

\begin{tabular}{|l|c|c|c|c|c|}
\hline & \multicolumn{1}{|c}{ Never } & Yearly & Several times a year & Monthly & Several times a month \\
\hline Indicate: & $7(7,5 \%)$ & $20(21,5 \%)$ & $51(54,8 \%)$ & $13(14,0 \%)$ & $2(2,2 \%)$ \\
\hline
\end{tabular}

Figure 10. Rate at which greening is a topic on the board or management meeting's agenda.

Another question aimed at identifying in which corporate activity fields greening has been explicitly incorporated. A distinction was made between procurement, manufacturing, planning, transport, and logistics, innovation and investment policy, quality management, strategic management, and HRM. The results point to three domains in which greening has been incorporated for a longer time and for which either a greening project has started recently or has been running for over a year:

1. innovation and investment management ( $75.3 \%$ of respondents);

2. strategic management (69.9\%);

3. transport and logistics $(65.6 \%)$.

Nevertheless, about $14 \%$ of respondents state that greening is not an actual topic in the field of transport and logistics. Scrutinizing the various respondent categories, it is noted that mainly shippers and retailers state that it is not a relevant topic yet $(20 \%)$. It is the only category in which there is a different top three, i.e., procurement is deemed the second most important management aspect in which greening has been incorporated. This however is consistent with the role of such actors in the supply chain. The service industry states that transport and logistics is the number one domain in which greening has been incorporated.

\subsection{Types of Green Supply Chain Measures}

Companies have a series of alternatives/options available for improving the environmental performance of their supply chains. These alternatives may include technological, process, or organizational characteristics. In an open question, respondents were asked to name the most obvious example of a green measure within the company. The long list of answers was reduced to 14 categories, amongst which five clearly yielded a significant number of answers (Figure 11):

1. Green energy (22).

2. Energy saving measures for transport (20).

3. Energy saving measures for infrastructure (17).

4. Modal shift / intermodal transport (15).

5. Alternative fuels for transport (14).

The best scoring greening measures typically relate directly to existing regulation and minimum standards. Those measures that relate to a real change in behavior or intrinsic motivators score substantially lower. 


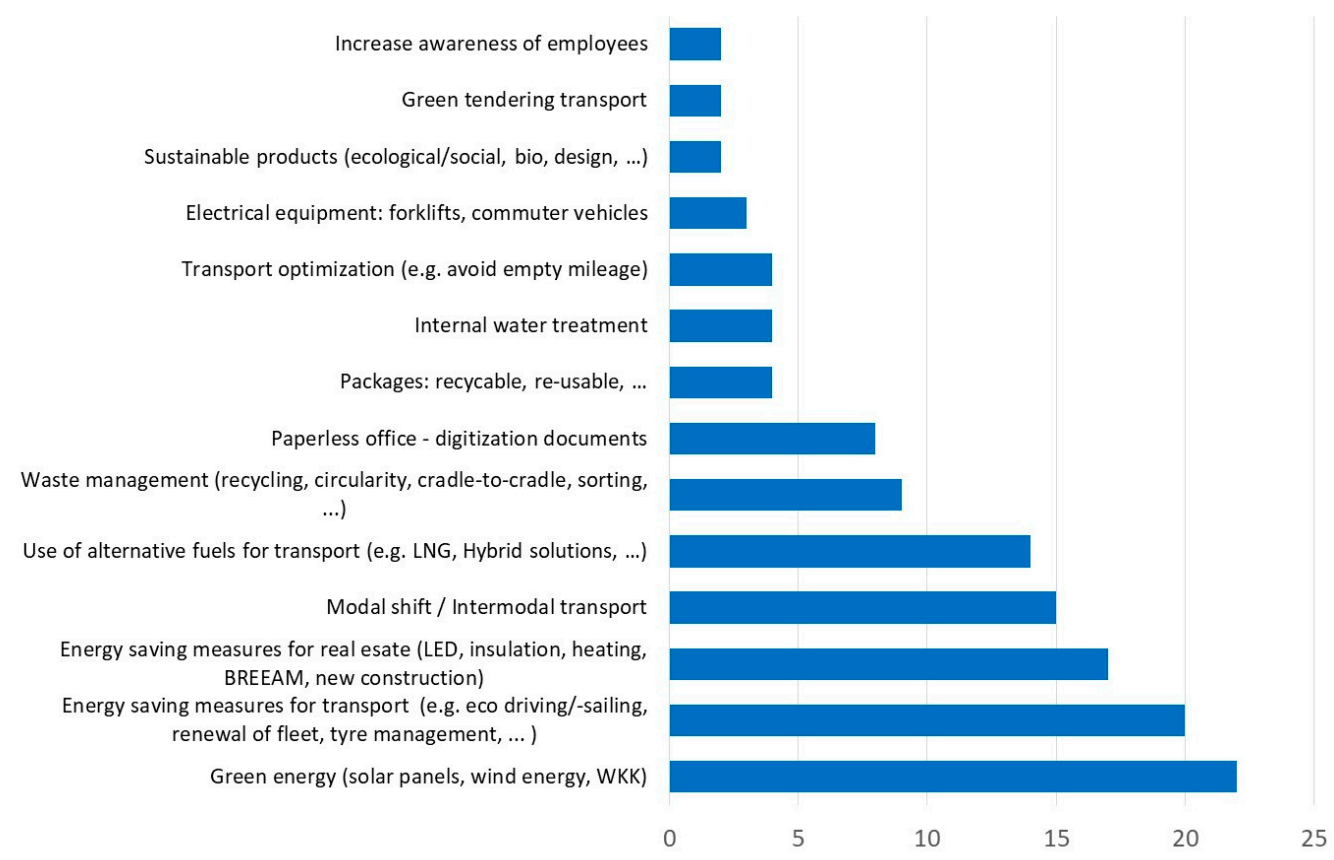

Figure 11. Implemented greening measures (number of mentions by respondents).

The survey also included questions on which actor is the driving force behind the development and implementation of green initiatives and how companies actively influence, or are influenced by, their supply chain partners. Virtually none of the respondents $(4.3 \%)$ states they are fully controlled by suppliers/customers when it concerns greening. Almost half (45.2\%) of the respondents state they are fully in control, whereas the rest $(50.5 \%)$ recognize that greening is a joint effort. When looking at how companies actively direct greening efforts, the top answers are:

1. Imposing specifications (26.9\%).

2. Actively stimulating supply chain collaboration (25.2\%).

3. Clearly stating that greening is an integral part of the evaluation process $(20.3 \%)$.

A clear majority (74\%) of respondent firms state they are doing more than what has been imposed by their clients. When asking about the drivers that push companies 'to do more', $45.1 \%$ of the mentioned drivers are directly linked to 'environment, climate, and social responsibility'. This figure outweighs the other motives to do more, such as reputation/image/marketing (about 17\%), strategic decision for long-term growth (15\%), and increased efficiency/profitability (12\%).

\subsection{Main Drivers and Barriers to GSCM}

Companies might initiate the implementation of environmental practices due to motivational drivers, such as sales to customers, and regulatory and stakeholder-related pressures. The survey reveals that the main motives of the respondents to aim for the greening of supply chains are of an economic and or social nature, with the following top 5 drivers (Figure 12):

1. Reputation of your company $(89.2 \%)$.

2. Focus on greening as new value creation activity $(73.1 \%)$.

3. Influence from society $(73.1 \%)$.

4. Demand (68.8\%).

5. Competitiveness (63.4\%). 


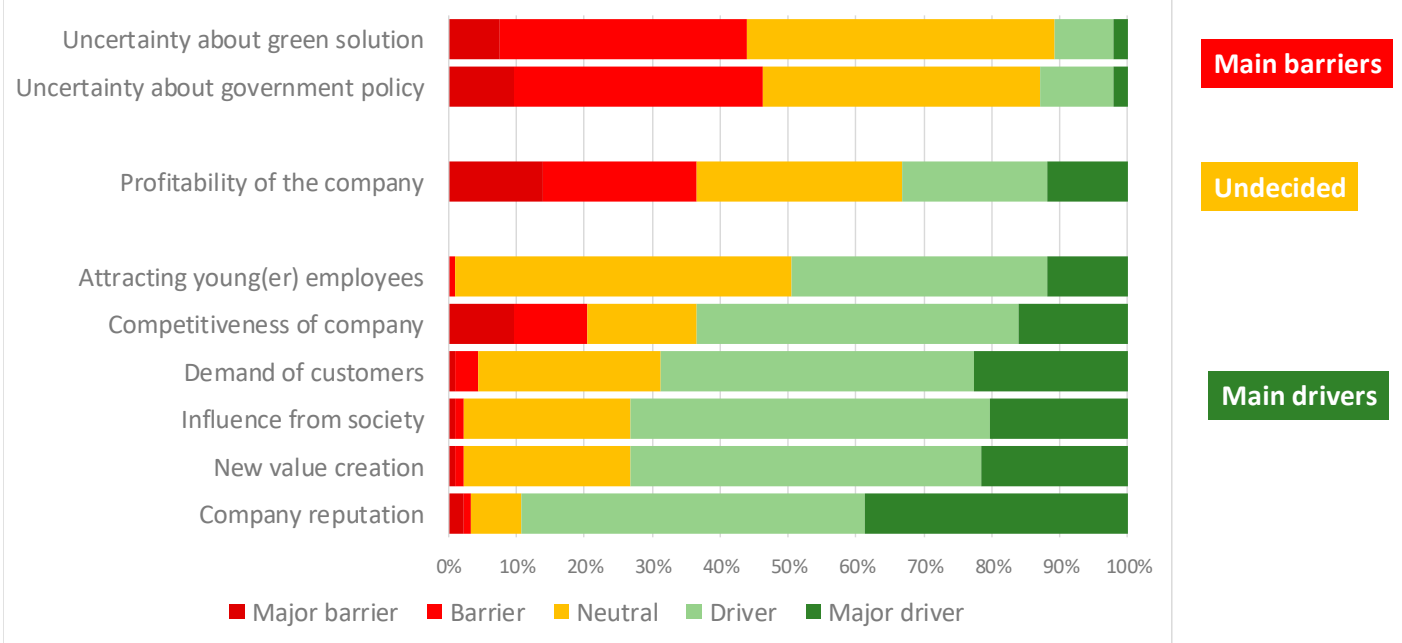

Figure 12. Main drivers and barriers to the greening of supply chains.

Almost half of the respondents (49.4\%) indicate it is important to attract young(er) employees. The World Economic Forum [56] argues that not opting for green supply chains can negatively affect companies' cost base and profitability, and that a focus on GSCM is needed to secure revenue growth, achieve cost reductions, develop brand value, and mitigate risks. Still, the survey results give a more diverse picture. Even though $33.3 \%$ of respondents see greening as a driver for the profitability of the company, almost an equal number (36.6\%) see it as a barrier. As the awareness among consumers and stakeholders about greening is increasing, companies feel the need to show commitment towards a greener production and supply chain without ignoring competitive advantage and positive business cases. Therefore, it is difficult to assess whether an initiative really represents a further greening of supply chains or a "greenwashing" campaign with no or very little impact on the environment.

When also considering the fact that $63.4 \%$ of companies surveyed see competitiveness as a clear motive to engage in greening (Figure 12), it could be concluded that greening indeed is required to maintain one's competitive edge, but that at the same time not everyone is convinced that it contributes to the company's profitability. This issue was further addressed by using another question in the questionnaire, i.e., do greening measures also yield earning opportunities? Figure 13 shows that more than two-thirds of the respondents see earning opportunities arising from new greening activities. Even though the group sees fewer chances into building on existing services and products, still, some $60 \%(59 \%)$ believe one should not just get rid of the old. It is furthermore hopeful to note that two-thirds $(66.6 \%)$ of the population does not consider greening to be a cost only.

\begin{tabular}{|l|c|c|c|c|c|}
\hline & Strongly disagree & \multicolumn{1}{|c}{ Disagree } & Neutral & Agree & Strongly agree \\
\hline Within current activities & $4(4,3 \%)$ & $7(7,5 \%)$ & $27(29,0 \%)$ & $41(44,1 \%)$ & $14(15,1 \%)$ \\
\hline In newly to develop activities & $1(1,1 \%)$ & $3(3,2 \%)$ & $23(24,7 \%)$ & $51(54,8 \%)$ & $15(16,1 \%)$ \\
\hline Greening is a cost only & $23(24,7 \%)$ & $39(41,9 \%)$ & $15(16,1 \%)$ & $14(15,1 \%)$ & $2(2,2 \%)$ \\
\hline
\end{tabular}

Figure 13. Yield earning opportunities of green initiatives.

In summary, companies cannot blindly roll out green initiatives as part of GSCM. Investment recovery is often cited as a critical aspect of GSCM. Logistics and supply chain managers have to balance efforts to reduce costs, improve service quality, increase flexibility, and innovate while maintaining good environmental (ecological) performance. When deciding on green initiatives, companies take into account the above strategic performance requirements, which may not be environmentally based, such as cost, return on investment (ROI), service quality, and flexibility. In other words, green initiatives 
should not only best support the green supply chain, but also result in a positive business case. Otherwise, the competitive and financial position of the company might be negatively affected.

When considering the barriers, it should be noted that the top three show less pronounced results as those noted under drivers:

1. uncertainty about continuity of funding and innovation stimuli from policy makers (46.3\%);

2. uncertainty whether the preferred greening solution is future proof $(44.1 \%)$;

3. profitability of the company $(36.6 \%)$.

Additionally, climate ambitions both on a local (national/regional) (45.2\%) and international and European $(43 \%)$ level are seen as drivers, even though they both have a large number of the population that is undecided $(43 \%)$.

Financial incentives or penalties given by public authorities (such as subsidies, tax breaks, etc. for green investments or penalties for non-compliance) or by private service providers (such as a commercial bank providing favorable loan conditions for green investments) are often very important in investment or divestment decisions and to achieve investment recovery. However, the survey shows the business world is very sensitive to coherence and continuity in the developed policy, the legal (un)certainty of implemented policies, and the enforcement of policies through inspection and control. As many investment decisions have a medium to long-term payback time, any changes in government policy (for example, the abolishment of a subsidy scheme for certain green investments) can have large ramifications on the soundness of the initial corporate decision related to a green initiative. Thus, government policies and regulation typically have a significant impact on green strategies, investments, and GSCM initiatives pursued by companies, but should provide legal and investment certainty to the affected companies.

\subsection{The Role of Government in GSCM}

There is an important role for (inter)national governments and organizations in driving the developments in green supply chains. Governments may act as catalysts for change. The environmental policies of governments and other public entities can have a significant impact on GSCM. These policies typically define the emission and energy targets (global, Europe, national) for economic activities. To reach these targets, a range of instruments and intervention mechanisms are available to public policy makers. For example, financial incentives and penalties of governments and public entities can affect the further greening of supply chains.

The survey contained a question related to the role of government in GSCM (Figure 14). The results show that $87.1 \%$ of the respondents state the government has a role as an information provider. This is partially supported by the expectation that the government should impose minimum standards. More than half (54.8\%) support this statement, when, at the same time, not a single respondent $(0 \%)$ thought this to be false. All shipping companies supported this statement. More than half $(52.7 \%)$ of the respondents think some form of intervention of the administration is desirable, with only about one in five $(18.3 \%)$ confirming they should not actively engage. Shippers and retailers are the most in favor, i.e., $80 \%$. Taxes as a tool to enhance the greening of supply chains is a contentious issue. Still, the group that recognizes $(41.9 \%)$ taxes as a tool is larger than the group that is opposed $(31.2 \%)$. Two thirds of respondents consider subsidies to be beneficial to greening. Especially the consolidated logistics service providers $(83.2 \%)$ show an interest. The overall results show that business wants government to be a soft enforcer. Companies want government to tell them how to proceed and to be stimulated to do so, but at the same time do not want to be punished too severely if they don't engage quickly enough. 


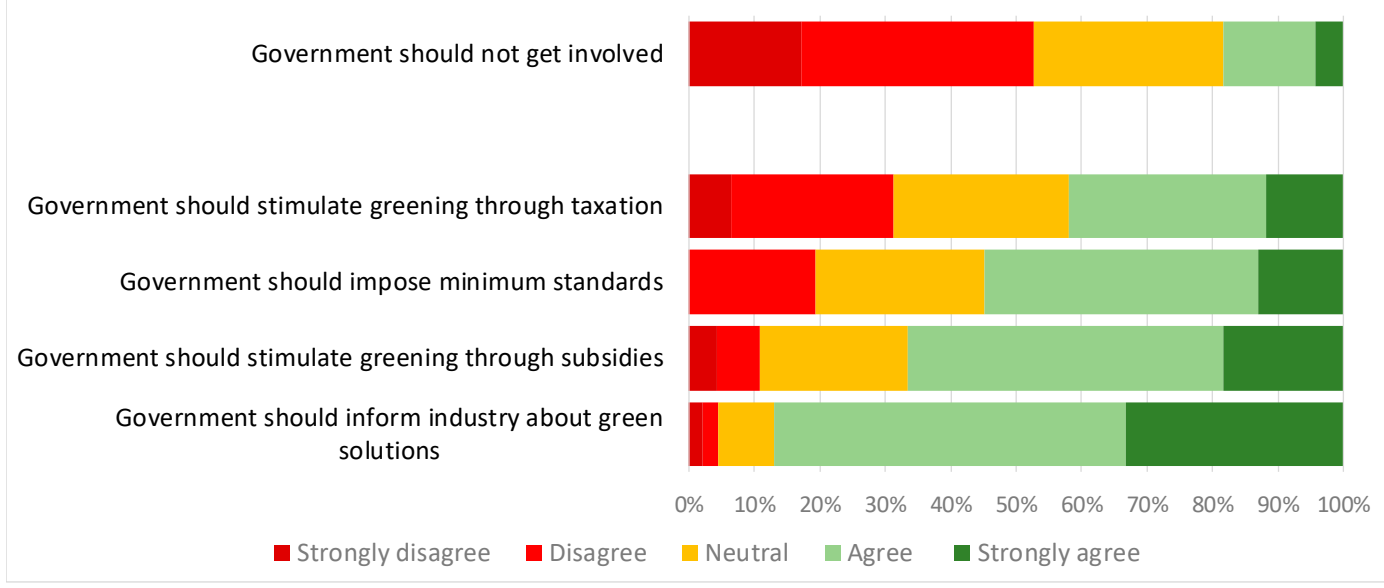

Figure 14. The role of government.

\subsection{Key Performance Indicators (KPIs) for Measuring and Reporting on Green Measures}

When engaging in GSCM initiatives, companies are challenged to measure the related performance. Existing literature provides a wide range of classifications, typologies, and overviews of possible Key Performance Indicators (KPIs) that can be used in a GSCM context (see e.g. [57-59]). Figure 15 provides insights on the KPIs being considered or used by the respondents. A clear top three emerges:

1. relative emission per delivered effort (e.g., tonkm) or manufactured unit (54.8\%);

2. impact on loading factor/utilization degree of vehicles (54.6\%);

3. absolute emissions (51.7\%).

\begin{tabular}{|l|c|c|c|c|c|}
\hline & $\begin{array}{c}\text { Strongly } \\
\text { disagree }\end{array}$ & Disagree & Neutral & Agree & Strongly agree \\
\hline Absolute emissions & $10(10,8 \%)$ & $4(4,3 \%)$ & $31(33,3 \%)$ & $34(36,6 \%)$ & $14(15,1 \%)$ \\
\hline Relative emissions per delivered performance (e.g. tonkm) or produced & $10(10,8 \%)$ & $4(4,3 \%)$ & $28(30,1 \%)$ & $35(37,6 \%)$ & $16(17,2 \%)$ \\
\hline Impact on sustainability rating/labels & $7(7,5 \%)$ & $6(6,5 \%)$ & $47(50,5 \%)$ & $25(26,9 \%)$ & $8(8,6 \%)$ \\
\hline Impact towards a green energy mix & $5(5,4 \%)$ & $11(11,8 \%)$ & $41(44,1 \%)$ & $27(29,0 \%)$ & $9(9,7 \%)$ \\
\hline Contribution to a green modal split & $6(6,5 \%)$ & $5(5,4 \%)$ & $39(41,9 \%)$ & $28(30,1 \%)$ & $15(16,1 \%)$ \\
\hline Impact on capacity use of vehicles & $11(11,8 \%)$ & $4(4,3 \%)$ & $27(29,0 \%)$ & $30(32,3 \%)$ & $21(22,6 \%)$ \\
\hline
\end{tabular}

Figure 15. Relevant KPIs in a green supply chain context.

The large groups of respondents expressing 'no opinion' however are somewhat disconcerting. It leads us to believe that these companies are not actively engaged in implementing and following up on KPI's within their companies. The top three for the larger companies is as follows:

1. relative emission per delivered effort (e.g. ton $\mathrm{km}$ ) or manufactured unit (70.9\%);

2. absolute emissions (70.8\%);

3. impact on loading factor of vehicles $(62.5 \%)$.

SMEs should define KPI's and implement them to increase their grip on the subject. When asking for other relevant key performance indicators, there were no indicators that collected a significant number of replies. However, indicators such as 'waste produced', 'use of water', 'particulate matter' are worth mentioning.

\subsection{To what Extent is Competition Between Ports and Companies Influenced by Greening Actions?}

Respondents state that greening mainly has an influence on the company's own competitiveness $(65.6 \%)$ and on the choice of the transport mode $(60.2 \%)$. It is striking that one third of the respondents' 
state it does not influence the choice of the port they use, even though the majority do not express an opinion on this statement (45.2\%), see Figure 16.

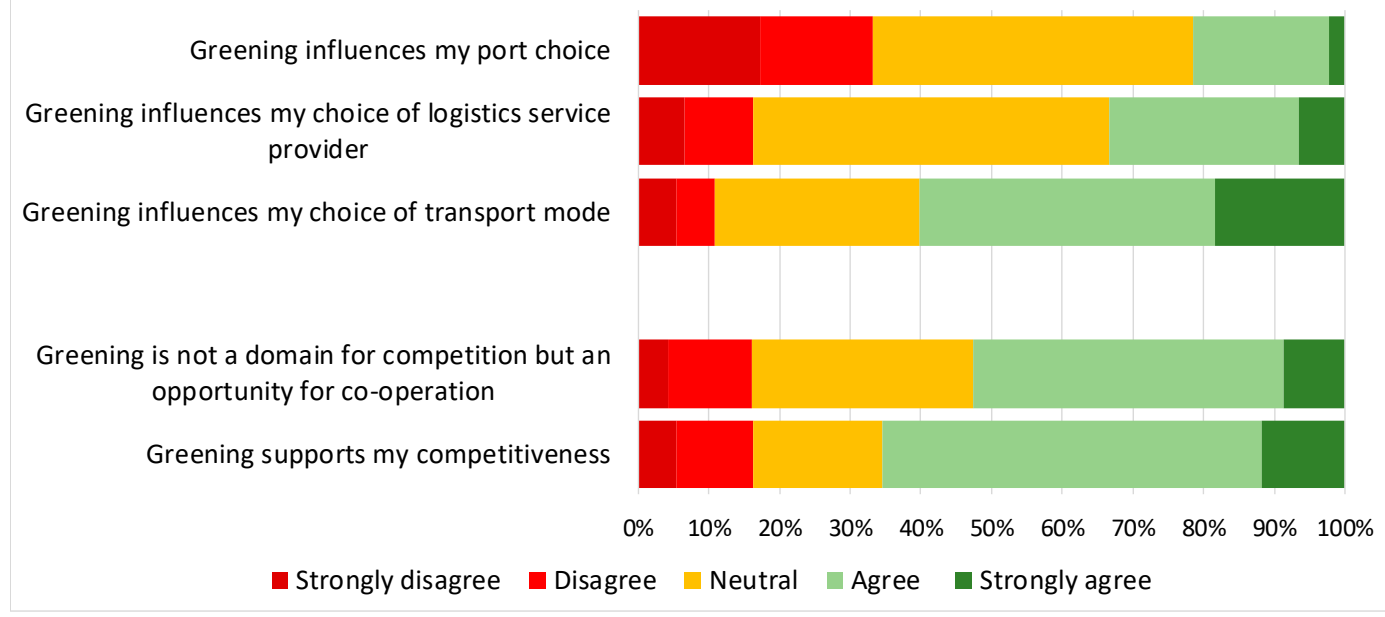

Figure 16. The impact of greening on competition and competitiveness.

Another striking result is the relatively low score (33.4\%) for the statement 'greening influences my choice of (port)logistics service provider'. Upon closer examination, a distinction can be made between large companies (37.5\%), shippers and retailers (45\%), and logistics service providers $(41.4 \%)$ that subscribe to this statement, and more port related companies that remain neutral on the matter, such as the shipping companies (80\%), terminal operators $(73.3 \%)$, and others $(81.8 \%)$. Finally, about half $(52.7 \%)$ of the respondents see greening as an opportunity for collaboration.

\section{Discussion and Conclusions}

Ports are hotbeds for initiatives aimed at a further greening of supply chains. To our knowledge, this paper is the first study providing a comprehensive analysis on initiatives, approaches, and perspectives of port-related actors in a specific multi-port region. While the empirical part of this research focused on the Rhine-Scheldt Delta port region, the conceptual typology of GSCM initiatives and overall findings of the survey can also provide valuable inputs to the ongoing discussions on the greening of port-related supply chains in other port regions around the world.

The long list of initiatives, actions, and projects for each of these domains illustrates that the port communities in the Rhine-Scheldt Delta are determined to reduce the environmental footprint of their activities and to make the transition to a more energy-efficient and circular economy. However, port communities also understand that the challenges remain immense and progress made is not at the same level in all domains of action. The port ecosystems are challenged to drastically decrease their environmental footprints against a background of growth in volumes and investments. This requires drastic and large-scale solutions such as Carbon Capture and Utilization (CCU) and Carbon Capture and Storage (CCS), a further push towards greener shipping, a strong modal shift, and adoption of synchromodality, etc. Ports are part of larger networks and chains; thus, requiring co-ordination and co-operation between the actors involved in these networks and chains, thereby facilitated by technology, governance and business models, and facilitation and regulation by governments.

Port-related actors involved in global supply chains are aware of the sense of urgency to move to greener supply chains. The survey confirms that greening has been put massively on the agenda by the firms between 2010 and now. However, one can still see a gap between words and actions as from the responding companies; roughly one in five is just-or still must-expand into effective action. In addition, actions relate largely to 'easy' measures quite often related to regulation and less to serious new innovations or changes in behavior or business models. Companies are keen to provide 'the right answer' but a diffuse image on the future, as well as some fear for the company's profitability, 
are holding some back. Still, the greening of supply chains does not have to be a burden but could constitute a potential source of competitive advantage. More than two-thirds of respondents see earning opportunities arising from newly to develop greening activities. Two thirds of the respondents do not consider greening to be a cost only.

There are diverse drivers towards the greening of supply chains, such as sales to customers, and regulatory and stakeholder-related pressures. However, companies cannot blindly roll out green initiatives as part of GSCM, and not all market players see GSCM as a business value driver. Companies seemingly are ambiguous on whether greening works positively on profits. Inconsistencies and discontinuity in government policies can lead to uncertainty negatively affecting or delaying green investment decisions and the associated development of business cases. The survey results show that the positive contribution to reputation of the company is a major driver, and in line with this is the ability to attract young employees, and the potential that greening offers for developing new value drivers within the company are highly valued. Governments may or should act as catalysts for change. The survey shows business wants government to be a soft enforcer, relying more on the 'carrot' approach instead of the 'stick' approach.

Based on the research outcomes, we formulate a number of considerations that should be taken into account by public and private organizations when further pushing the green agenda forward in a port context, particularly in the Rhine-Scheldt delta region.

First, the positive green attitude of supply chain actors involved in ports and their commitment towards a further green development of their activities should be fully recognized and embraced. It is a joint responsibility of the port ecosystems to identify how to rightly tap upon the companies' underlying wish or nice feeling while 'doing good' in order to accelerate actions in the field of the greening of supply chains.

Second, the port and logistics sector is already communicating and exchanging ideas on plans and real achievements in the area of green supply chains. Port ecosystems need to intensify their efforts in this area as it is expected this aspect is going to become even more important in the coming years. The greening of supply chains demands a further mentality shift and joint commitment and dedication of all parties involved. Companies often act in a position of short-term survival. This asks for a continuous joint attention for the concern of individual companies in terms of uncertainty, for the question on how their business cases can be improved, or where compensation can be found for a thin business case or for the risk that other actors stop cooperating. More than ever, market actors will have to call out to other partners in the chains (including final customers) on how they can help companies achieve green corporate and societal objectives. Success typically depends on coordination and co-operation between the actors involved and the availability, use and sharing of data through appropriate (planning) platforms and systems. Risk and uncertainty are serious bottlenecks here, while trust between parties is an important enabler.

Third, progress remains difficult in some areas. While supply chain actors indicate that greening certainly is on their agendas and sometimes already for quite long, real actions sometimes stay behind, especially those that imply new business processes, and even more if this is in collaboration with other supply chain actors. Slow progress in the implementation of certain green initiatives in port-related supply chains does not point to unwillingness or ignorance of the relevant actors. It typically reflects the complexity and co-ordination needs linked to these initiatives and the corporate reality of the 'business case' approach.

There are also specific challenges for the industrial function of ports. The environmental impact of seaports is typically significant given the large concentration of activities. However, the clustering of activities in one location can also exert strong environmental advantages. It is imperative that these 'ecologies of scale' advantages are fully acknowledged in environmental policy. Still, CCU and CCS will be indispensable in view of meeting the $\mathrm{CO} 2$ reduction targets. The emerging cross-border and inter-port co-operation on this theme in the Delta is a positive step to bring its implementation to the next level. When it comes to the energy transition, it is important for port ecosystems to explore 
and contribute to the development of a wide range of initiatives that support a transition to more renewable energy, and not to narrow their focus to only one renewable energy source. Furthermore, port ecosystems are expected to develop further into key locations for recycling activities and the re-use of materials in the context of the transition towards a circular economy. Ports should be given the possibility to fully adopt this role through an appropriate regulatory framework, knowledge development, and infra- and superstructure.

A last set of considerations relates to the role of port authorities. Port authorities in the Rhine-Scheldt Delta are very visible in facilitating the greening of supply chains and the transition to a circular economy and non-fossil fuel-based economy. Examples include voluntary programs to promote the development and use of green ships, extensive coordinated initiatives to enhance a modal shift and synchromodality in hinterland transport, and a whole range of actions and plans in the area of CCU and energy transition. Port authorities should evaluate whether they have a role to play (i.e., will their involvement likely lead to a superior outcome compared to no involvement?), what tools or instruments to use (e.g., pricing, knowledge development/sharing, investment, etc.), and whether they should act as facilitator or entrepreneur. In some cases, port authorities move beyond the pure facilitating role by entering into key investments, particularly in those cases where private investors show more reluctance to do so. While port authorities are very active in materializing the green port concept, one should acknowledge that progress remains difficult in some areas, such as the large-scale implementation of cold ironing solutions for deep sea vessels, or the greening of terminal concession procedures and agreements. Given the position of seaports as key nodes in global supply chains and logistics networks, it is tempting to push port authorities to take up a role as tax collectors for environmental damage caused throughout these chains and networks. Port authorities should not be forced by policy makers at the supranational or national level to act as the convenient tax collectors for the greening of supply chains. Any internalization of environmental costs should target the polluter at the source and cannot lead to an obligation for port authorities to punish for externalities or to reward environmental performance. Obviously, the above point does not imply that port authorities should refrain from launching such schemes on a voluntary basis (individually or together with other ports).

Author Contributions: Conceptualization, T.N.; methodology, all authors; formal analysis, all authors; writing-original draft preparation, T.N.; writing-review and editing, all authors. All authors have read and agreed to the published version of the manuscript.

Funding: The research that formed the basis for the development of this paper received external funding from ING Belgium in the context of the research project 'Green supply chains: Implications and challenges for Rhine-Scheldt Delta seaports'. This project was conducted by the authors of this paper in the first half of 2019.

Acknowledgments: This research paper could not have been developed without the support of ING Belgium. The authors would like to express gratitude to Bram Debruyne and Yves Goddefroy (ING) and all other members of the steering committee of the above-mentioned research project: Karen Polfliet (North Sea Port), Patrick Van Cauwenberghe (MBZ - port of Zeebrugge), Chris Coeck (Port of Antwerp), Dirk Vanhoutteghem (Gosselin Group), Yves De Larivière (Antwerp Euroterminal), Stephan Vanfraechem (VOKA), Kris Liesse (ING), Pieter Baan (ING), and Marc Callier (ING). The views expressed in this paper reflect the authors' views on the subjects discussed.

Conflicts of Interest: The authors declare no conflict of interest.

\section{References}

1. Ahi, P.; Searcy, C. A comparative literature analysis of definitions for green and sustainable supply chain management. J. Clean. Prod. 2013, 52, 329-341. [CrossRef]

2. Sarkis, J.; Zhu, Q.; Lai, K.-H. An organizational theoretic review of green supply chain management literature. Int. J. Prod. Econ. 2011, 130, 1-15. [CrossRef]

3. Srivastava, S. Green supply-chain management: A state-of-the-art literature review. Int. J. Manag. Rev. 2007, 9, 53-80. [CrossRef]

4. Frosch, R.A.; Gallopoulos, N.E. Strategies for Manufacturing. Sci. Am. 1989, 261, 144-152. [CrossRef]

5. E Porter, M.; Van Der Linde, C. Toward a New Conception of the Environment-Competitiveness Relationship. J. Econ. Perspect. 1995, 9, 97-118. [CrossRef] 
6. Van Hoek, R.I. From reversed logistics to green supply chains. Supply Chain Manag. Int. J. 1999, 4, $129-135$. [CrossRef]

7. Wilkerson, T. Best practices in implementing green supply chains. In Proceedings of the North America Supply Chain World Conference and Exposition, Washington, DC, USA, 4-6 April 2005; LMI Consulting: Anaheim, CA, USA, 2005.

8. Sarkis, J. A strategic decision framework for green supply chain management. J. Clean. Prod. 2003, 11, 397-409. [CrossRef]

9. Christmann, P.; Taylor, G. Globalization and the environment: Determinants of firm self-regulation in China. J. Int. Bus. Stud. 2001, 32(3), 439-458. [CrossRef]

10. Lowe, E. Industrial ecology—an organizing framework for environmental management. Environ. Qual. Manag. 1993, 3, 73-85. [CrossRef]

11. Coglianese, C.; Nash, J. (Eds.) Regulating from the Inside: Can Environmental Management Systems Achieve Policy Goals? Resources for the Future: Washington, DC, USA, 2001.

12. Darnall, N.; Jolley, G.J.; Handfield, R. Environmental management systems and green supply chain management: complements for sustainability? Bus. Strat. Environ. 2007, 17, 30-45. [CrossRef]

13. Van Der Horst, M.R.; De Langen, P. Coordination in Hinterland Transport Chains: A Major Challenge for the Seaport Community. Marit. Econ. Logist. 2008, 10, 108-129. [CrossRef]

14. Notteboom, T. The adaptive capacity of container ports in an era of mega vessels: The case of upstream seaports Antwerp and Hamburg. J. Transp. Geogr. 2016, 54, 295-309. [CrossRef]

15. Pavlic, B.; Cepak, F.; Sucic, B.; Peckaj, M.; Kandus, B. Sustainable port infrastructure, practical implementation of the green port concept. Therm. Sci. 2014, 18, 935-948. [CrossRef]

16. Doerr, O. Sustainable port policies. Bull. FAL 2011, 299, 1-8.

17. Lam, J.S.L.; Notteboom, T. The Greening of Ports: A Comparison of Port Management Tools Used by Leading Ports in Asia and Europe. Transp. Rev. 2014, 34, 169-189. [CrossRef]

18. Acciaro, M.; Vanelslander, T.; Sys, C.; Ferrari, C.; Roumboutsos, A.; Giuliano, G.; Lam, J.S.L.; Kapros, S. Environmental sustainability in seaports: a framework for successful innovation. Marit. Policy Manag. 2014, 41, 480-500. [CrossRef]

19. Puig, M.; Wooldridge, C.; Michail, A.; Darbra, R.M. Current status and trends of the environmental performance in European ports. Environ. Sci. Policy 2015, 48, 57-66. [CrossRef]

20. Merk, O. Shipping Emissions in Ports. Int. Transp. Forum Discuss. Pap. 2014.

21. Wang, S.; Notteboom, T. The Adoption of Liquefied Natural Gas as a Ship Fuel: A Systematic Review of Perspectives and Challenges. Transp. Rev. 2014, 34, 749-774. [CrossRef]

22. Wang, S.; Notteboom, T. The role of port authorities in the development of LNG bunkering facilities in North European ports. WMU J. Marit. Aff. 2015, 14, 61-92. [CrossRef]

23. Notteboom, T.; Lam, J.S.L. The Greening of Terminal Concessions in Seaports. Sustain. 2018, 10, 3318. [CrossRef]

24. Daamen, T.A.; Vries, I. Governing the European port-city interface: institutional impacts on spatial projects between city and port. J. Transp. Geogr. 2013, 27, 4-13. [CrossRef]

25. Bui, M.; Adjiman, C.S.; Bardow, A.; Anthony, E.J.; Boston, A.; Brown, S.; Fennell, P.S.; Fuss, S.; Galindo, A.; Hackett, L.A.; et al. Carbon capture and storage (CCS): the way forward. Energy Environ. Sci. 2018, 11, 1062-1176. [CrossRef]

26. Wilmsmeier, G.; Spengler, T. Energy consumption and container terminal efficiency. UN ESCAP 2016.

27. Schmidt, J.; Meyer-Barlag, C.; Eisel, M.; Kolbe, L.M.; Appelrath, H.-J. Using battery-electric AGVs in container terminals-Assessing the potential and optimizing the economic viability. Res. Transp. Bus. Manag. 2015, 17, 99-111. [CrossRef]

28. Chen, G.; Govindan, K.; Yang, Z. Managing truck arrivals with time windows to alleviate gate congestion at container terminals. Int. J. Prod. Econ. 2013, 141, 179-188. [CrossRef]

29. Huynh, N.; Walton, M.C. Robust Scheduling of Truck Arrivals at Marine Container Terminals. J. Transp. Eng. 2008, 134, 347-353. [CrossRef]

30. Bentolila, D.J.; Ziedenveber, R.K.; Hayuth, Y.; Notteboom, T. Off-peak truck deliveries at container terminals: the "Good Night" program in Israel. Marit. Bus. Rev. 2016, 1, 2-20. [CrossRef]

31. Behdani, B.; Fan, Y.; Wiegmans, B.; Zuidwijk, R. Multimodal Schedule Design for Synchromodal Freight Transport Systems. SSRN Electron. J. 2014, 424-444. [CrossRef] 
32. Tavasszy, L.; Behdani, B.; Konings, R. Intermodality and Synchromodality. In Ports and Networks; Routledge: Abingdon upon Thames, UK, 2017; pp. 251-266.

33. Pfoser, S.; Treiblmaier, H.; Schauer, O. Critical Success Factors of Synchromodality: Results from a Case Study and Literature Review. Transp. Res. Procedia 2016, 14, 1463-1471. [CrossRef]

34. Cruijssen, F.; Cools, M.; Dullaert, W. Horizontal cooperation in logistics: Opportunities and impediments. Transp. Res. Part E: Logist. Transp. Rev. 2007, 43, 129-142. [CrossRef]

35. Van den Berg, R.; De Langen, P.W. Towards an 'inland terminal centred'value proposition. Marit. Policy $\mathcal{E}$ Manag. 2015, 42(5), 499-515.

36. Rodrigue, J.-P.; Notteboom, T. The terminalization of supply chains: reassessing the role of terminals in port/hinterland logistical relationships. Marit. Policy Manag. 2009, 36, 165-183. [CrossRef]

37. Visser, J.G. The development of underground freight transport: An overview. Tunn. Undergr. Space Technol. 2018, 80, 123-127. [CrossRef]

38. Bergqvist, R.; Egels-Zandén, N. Green port dues - The case of hinterland transport. Res. Transp. Bus. Manag. 2012, 5, 85-91. [CrossRef]

39. Zhang, X.; Zeng, Q.; Yang, Z. Optimization of truck appointments in container terminals. Marit. Econ. Logist. 2018, 21, 125-145. [CrossRef]

40. Preston, F. A Global Redesign? Shaping the Circular Economy; Chatham House: London, UK, 2012.

41. Van Dooren, N.; Braam, G. The Netherlands as a Circular Hotspot. 2015. Available online: http://greenalliance.org.uk/resources/6 (accessed on 20 February 2020).

42. Chertow, M.R. Industrial symbiosis: literature and taxonomy. Annu. Rev. Energy Environ. 2000, 25(1), 313-337. [CrossRef]

43. Kuipers, B. Ports as catalysts for change towards a circular economy: Illustrations from the ports of Amsterdam and Antwerp. In Proceedings of the ESPO Conference, Athens, Greece; 22 May 2015; Erasmus UPT: Rotterdam, The Nederland, 2015.

44. De Langen, P.; Sornn-Friese, H. Ports and the Circular Economy; Elsevier BV: Amsterdam, The Netherlands, 2019; pp. 85-108.

45. Grewal, D.; Darlow, N.J. The Business Paradigm for Corporate Social Reporting in the Context of Australian Seaports. Marit. Econ. Logist. 2007, 9, 172-192. [CrossRef]

46. Vanelslander, T. Seaport CSR: innovation for economic, social and environmental objectives. Soc. Responsib. J. 2016, 12, 382-396. [CrossRef]

47. Maigret, A. Sustainability Reporting in the Port Sector. Master's Thesis, Lund University, Lund, Sweden, 22 October 2014.

48. Geerts, M.; Dooms, M. Sustainability reporting by port authorities: a comparative analysis of leading world ports. In Proceedings of the IAME 2017 Conference, Kyoto, Japan, 27-30 June 2017; The International Association of Maritime Economist: Galveston, TX, USA, 2017.

49. Dooms, M.; Verbeke, A.; Haezendonck, E. Stakeholder management and path dependence in large-scale transport infrastructure development: the port of Antwerp case (1960-2010). J. Transp. Geogr. 2013, 27, 14-25. [CrossRef]

50. Parola, F.; Maugeri, S. Origin and taxonomy of conflicts in seaports: Towards a research agenda. Res. Transp. Bus. Manag. 2013, 8, 114-122. [CrossRef]

51. Brewer, P.C.; Speh, T.W. Adapting the balanced scorecard to supply chain management. Supply Chain Manag. Rev. 2001, 5, 48-56.

52. Berg, R.V.D.; De Langen, P. An exploratory analysis of the effects of modal split obligations in terminal concession contracts. Int. J. Shipp. Transp. Logist. 2014, 6, 571. [CrossRef]

53. Stad Gent, North Sea Port. Naar een nieuwe koolstofarme economie in het havengebied van Gent: Verkennende studie voor de ontwikkeling van Carbon Capture \& Utilisation voor het havengebied Gent. Available online: https://stad.gent/sites/default/files/media/documents/CCUhub_Rapport.pdf (accessed on 20 February 2020).

54. Veenstra, A.; Zuidwijk, R.; Van Asperen, E. The extended gate concept for container terminals: Expanding the notion of dry ports. Marit. Econ. Logist. 2012, 14, 14-32. [CrossRef]

55. Kopicki, R.; Berg, M.J.; Legg, L. Reuse and Recycling-Reverse Logistics Opportunities; Council of Supply Chain Management Professionals: IL, USA, 1993. 
56. World Economic forum. Beyond Supply Chains Empowering Responsible Value Chains. Report prepared in co-operation with Accenture, REF 070115. 2015.

57. Hervani, A.A.; Helms, M.M.; Sarkis, J. Performance measurement for green supply chain management. Benchmarking: Int. J. 2005, 12, 330-353. [CrossRef]

58. Epstein, M.J.; Wisner, P.S. Using a Balanced Scorecard to Implement Sustainability. Environ. Qual. Manag. 2001, 11, 1-10. [CrossRef]

59. Beamon, B.M. Measuring supply chain performance. Int. J. Oper. Prod. Manag. 1999, 19, 275-292. [CrossRef]

(C) 2020 by the authors. Licensee MDPI, Basel, Switzerland. This article is an open access article distributed under the terms and conditions of the Creative Commons Attribution (CC BY) license (http://creativecommons.org/licenses/by/4.0/). 